\title{
幼児の左右反転弁別における言語媒介の発達
}

\author{
橋 本 憲 尚* \\ DEVELOPMENT OF VERBAL MEDIATION IN LEFT-RIGHT ORIENTATION \\ DISCRIMINATION IN PRESCHOOL CHILDREN
}

\section{Norihisa Hashimoto}

\begin{abstract}
Summary: There has been few analyses of relationship between verbal coding/mediation skill and task performance in children's left-right orientation discrimination. In this study, verbal coding skill was evaluated from expression of the orientations of pictures presented prior to the task, and verification of verbal mediation was gained from expression of the response labels used in the task. Developmental change of verbal mediation skill was found in preschool years, although the task was easy to resolve even with nonverbal mediation. Utility of nonverbal mediation in a discrimination task and the nature of a transitional level featured by nonverbal mediation in spite of verbal coding skill were discussed.
\end{abstract}

Key words : left-right orientation discrimination, preschool children, verbal mediation.

\section{問 題}

幼児が平気で本を逆さにしたり横向きにしているのを 見ると, 彼らは絵の向きには無頓着であるかのように思 われる。従来，「幼児は一般に刺激を空間枠組の中に関 係づけることができない」(Wohlwill, 1960)とされてきた のもそのためである。特に，左右反転弁別は幼児にとっ て困難であると繰り返し報告されてきた（例えば，Davidson, 1935 ; 勝井, 1971 ; Rudel \& Teuber, 1963)。ところ が, 近年, 教示言語の理解の負担を軽減する (Flavell, 1971）もしくは実験場面に扔いて暗黙のうちに前提とさ れているルールの理解を促進させる (Gelman, 1978) 手続 をとれば，年少児でも十分正確に弁別しうるといら実験 結果が散見されるようになった。例えば，むきの次元に ついて「同じ」と判断すべきであることを理解させる訓 練を与えておくとマッチング課題は容易に解決される (Caldwell \& Hall, 1969), ラベリングについての教示に先 立って左右方向に注目するように教示しておく，あるい は絵を提示してむきを問うことにより左右の表現を行わ せておくと弁別課題の成績が促進される（橋本，1985）と いう。これらに従うと, むきに関する概念は遅くとも 4

* 高知大学教育学部 (Faculty of Education, Kochi University)
歳頃までに獲得されているといえる。

ところで，上述のような手続の効果は，言語媒介が促 進された故に生じたのであ万うか。即ち, 言語媒介仮説 に従えば，教示あるいは訓練により幼児が左右のむきを 言語により符号化する傾向が増大し，言語媒介が行われ やすくなったため弁別課題の成績が向上したと考えられ る。本研究の目的は, 左右反転弁別課題解決にとって言 語媒介が必要技能であるか否かを検証し, 幼児期に打け るその発達変化を明らかにすることにある。

従来, 空間関倸汇関する言語理解については多くの凟 料を得ている。例えば，身体の左右を指摘させる言語理 解テスト結果から，自己身体の両侧を「ミギ」「ヒダリ」 という語で正しく区別しらるといえるのは 5-6 歳とさ れている (Laurendeau \& Pinard, 1970)。しかしながら, 弁別課題成績と弁別次元に関する言語的能力との関連に ついてはほとんど研究されていない。数少ない研究の 1 つとして，5-7 歳児に図形で表わされた空間関係に関 する視覚弁別課題 (同時マッチング) と言語理解課題を課 した Asso \& Wyke (1970) の研究がある。だが, 彼らの 得た結果は, どの年齢グループにおいても前者の方が容 易であり，両課題成績間に有意な相関注見いだせないと いうものであった。このような結果は, 弁別課題が弁別 次元の言語理解を構成要素として含んでいないことから 
すれば当然であるかもしれない。弁別課題が要求してい るのは刺激の符号化および反応の媒介であるわけだから， 言語理解でなく言語表現と課題成績の関連に焦点を当て なくてはならない。

本研究では, 幼児にとって教示手続上での言語理解の 負担が少ない弁別学習課題を用い，その課題成績と課題 前に行った絵のむきにっいての表現, 課題後に行った学 習されたラベルについての表現との関連の分析を試みる。 弁別課題解決にとって言語媒介が必要条作であるか否か を柃証するためには，被験者がもともと弁別刺激を言語 によって符号化する潜在的技能を所持していたのかどう かを判定し，そして䛞題遂行の際に言語媒介を自発的に 行ったか否かを推定する必要がある。そこで, 課題前に はテスト刺激とは異なる刺激を提示しながら，課題後に は刺激提示せずに左右のむきに関する同じ質問を行うこ ととした。

弁別学習課題においては被験者は，弁別されるべき刺 激次元を理解し， 2 種の刺激に対して異なる反応を行う ことを求められる。これが可能となるためには弁別され るべき次元に従って 2 種の刺激が各々符号化され，続い て各符号と各反応との連合が強化されなくてはならない。 ここで各符号は各刺激と反応を媒介する役割を果たすが， 媒介子は心的に生じるものであって通常外的には観察さ れず，推定せざるをえない。Reese (1978) は対連合学習 における媒介子の推定法として 5 つ取り上げているが, 弁別学習事態一の適用性, 刺激材料が絵であること, 年 齢の異なる幼児グループ間の比較を行うといった制限を 考虑すれば，以下の 2 方法の利用が可能であろう。

まずひとつには, 特定の媒介方略を行うよう教示して 成績を比較する方法が考えられる。「ミギ」「ヒダリ」と いった言語を用いて左右むきの絵を符号化し，反応を媒 介するよう教示しておいた群の成績が，教示を与えなか った群の成績より優れていれば，言語による媒介を行っ た方が幼児は左右反転弁別学解決しやすいといえよう。 しかしながら，これは実際に使用された媒介子を推定す るには間接的な方法に過ぎない。なぜなら，幼児が教示 どおりの方略を用いたかどうかは確約されないからであ る。教示された方略を使用するに注より以上の心的努力 を必要とするため回避する，あるいは教示された方略が 別な方略を喚起するなどの可能性は排除できない。つま り，個々の被験者の自発的な媒介反応を推定するのでは なく, 被験者に特定の媒介反応を強要するところに難点 がある。

もうひとつは自己報告法である。被験者によって報告 された媒介子が言語的であるか否か沈明確に分類可能で
あるから，より直接的な証左を得ることができる。しか し，Reese (1978) が指摘しているように, 報告そのもの が実際に使用された媒介子を表現したものであるという 保障はない。被験者が自分が使用した媒介子について思 い込んでいることを述べたに過ぎないかもしれないし， 質問のしかたによって報告が微妙に変わる可能性がある。 また幼児の場合，質問の意味がわからない，そもそも自 分の行動をモニターする能力に限界があるなどの理由で 報告できない危険性もある。

しかしながら，被験者が課題遂行の際に言語媒介を自 発的に行ったか否かを推定するためには，自己報告法に 頼らざるをえない。しかも橋本 (1985)によると, 絵のむ きについて回答することを明らかにした質問（「どっちへ いったら〜くん・ちゃんの (先生の) 絵?)」を行えば， 3 歳 児ですら弁別課題成功者すべてがラベルに対応する左右 むきを正しく指摘することができたと報告している。そ こで, 本研究では自己報告法の欠点を補うょう質問のし かたに以下の 2 点で工夫を施した。第 1 に，いくつかの 異なった質問を繰り返すことにより幼児自身による表現 をできるだけ引き出すこと。特に, 被験者の潜在的な符 号化能力を評定するためには，問題とされる次元につい て表現する機会をできるだけ与えることが必要と考え， 課題前質問の回数を多くする。第 2 亿, 課題後の質問で は課題中に憶えたり考えたりしたことを直接的に問うの ではなく，反応ラベルについての質問を行うことにより， 自分の行動をモニターすることをあまり意識させること のないよう配慮する。以上を踏まえて，具体的には「ど うなっていた?」という2つのラベルに対応する絵の差 異を問題にしているが，絵の如何なる側面について回答 すべきか滛昧な質問と，「どっちへ行ってた？」「何む きだった？」というむきについて回答すべきことを明確 にした質問を行った。後者汇関しては，動作表現，言語 表現を喚起しやすいと考えられる質問をそれぞれ行うこ とによって，媒介子の推定にかかる質問によるバイアス を排除することをねらったものである。

\section{方法}

(1)被験者 幼稚園あるいは保育所に在籍している4 歳 児 ( 4 藏 1 か年一11か月, 平均 4 藏 6 か月), 5 歳児 ( 5 筬 0 か月一-11か月, 平均 5 歳 6 か月), 6 歳児 ( 6 歳 1 か月一-10か月, 平均 6 歳 4 か月) の各年龄群 12 名 (男児, 女児各 6 名ずつ)ず つの計36名。

(2)趾置・刺激材料 直径 $60 \mathrm{~cm}$ ，奥行き $60 \mathrm{~cm}$ の木製 チューブの先端中央に直径 $24 \mathrm{~cm}$ の提示画面を設定し, 画 面中央に刺激絵が提示されるようチニーブの反対側のボ 
ックス内に刺激カード束をセットしておいた。チューブ 内は提示画面以外は黒塗りだが，実験者 1 の手元にある スイッチ操作により, 被験者側ののぞき空 (縱 $6 \mathrm{~cm}$ 以横 12 $\mathrm{cm})$ の上下から20wの蛍光灯で照らすようになっていた。

刺激カード(4つ切り白画用紙)に徒示再面に対して適 切な位置にある直径 $8 \mathrm{~cm}$ の冈内にちようど收安るよう， 太さ $1.2 \mathrm{~cm}$ の照㧍きの絵のコピーが貼付されていた。 左右のむきが明確な乘り物，動物それぞれ 7 ずつの絵が 刺激として提示された。誯题前質間およびトレーニング ではウサギ・クルマ, 般化テストではヘリコプター・フ ネ・ヒコーキ・キシャ・トラック・ジテンシャ・サカナ・ カメ・イヌ・ペンギン・ゾウ・ニワトリの絵灾使用した。 これらは, 帮䟻前に実験に参加しない4祡児10名に呼称 を求めた結果，年少児にとっても比較的見慣れた絵であ ると判断された。

(3)手続 笑験注幼稚園, 保育所の保健室に拉いて個別 に行った。幼巟用テーブルの中央にセットしておいたチ ニーブの正面中央ののぞき空に正詨するように被験者を 座らせ，その右側に実験者 1 が座って教示を与え，被験 者の反応妾記録した。チニーブの反対側には实駼者 2 が 座り，各実験セッションごとに系列化された刺激カード 束を紙芝居の萑領で操っていった。

(1) 呼称 すべての絵カード14枚を順次提示してゅき, そのつど「これは何の絵？」と問うた。被歌者の使用し た名称をそのまま記録し, わからないと意志表示した場 合にのみおとなが用いる名称を教えた。䦤始前に一緹に 遊ぼうと誘導しておき，垁検場面に慣れさせることに努 めた。

(2) 課題前質問 ウサギ・クルマの左右むきの絵，計 4 枚をランダム順に提示し，そのつど絵が「どうなって いる？」(以下 Q1 とする)と問うた。続いて提示順を変え て「どっちへ行く？」(同 Q2)，さらに同籙にして「何 むき！」(同 Q3）と問うた。以上, 計12回質問を行い, そのつど被験者が示す穹語反応や動作を記録した。

(3) トレーニング ウサギの左右むきの絵のらち一方 を提示して，「こんな絵は(被験者名)くん・ちゃんの絵」, 他方を提示して「こんな絵は先生の絵」だと教示してお き,これを逆順に繰り返した後, 以後に提示される絵が 被験者の絵なら「〜くん・らゃんの」, 先生の絵なら「先 生の」と応えるよう求めた。まず左右むき 1 回ずつ提示 し，被験者のラベリングに誤りがあれば訂正してから試 行を始めた。刺激カードは左右むき 4 枚ずつを同じむき が 3 回以上連続しないよう系列化しておき, その系列を 繰り返し提示した。被験者のラベリングに対し正誤フィ ードバックを与えながら, 連続 9 試行中 8 回正答すれば
次に進んだ。24試行中にこの基準に達しない場合にはそ の封点で弁別課題を中止し, 課題後質問に進んだ（トレ ーニング 1)。次に刺激絵をクルマに変えて同じ手続を繰 り返した(トレーニング2)。さらに，ラベルに関する教示 を行うことなく，ウサギ・クルマの左右むきの絵2效ず つを同じ絵，同じむきが 3 回以上連続しないよう系列化 しておいたものを繰り返し提示してラベリングを求的た (トレーニング 3 )。

(4) 般化テスト ラベルに関する教示を行うことなく, ウサボ・クルマ以外の12の絵の左右むき在順次提示して, フィードバックを与えずにトレーニングでのラベリング を求功た。左右むき，絵の類別 (動物・乘り物)について 全24試行中前装・後半でバランスをとり, 同一要素が 3 回以上連続しないよう提示した。

(5) 課題後罂問 刺激堤示を行わず，「〜くん・ちゃ んの絵」,「先生の絵」について, 課題前質問と阁様まず Q1, 続いて Q2, 最後にQ3の計6回質問を行い, その つど被駼者が示す言語反応や動作定記録した。

なお，各年䍅ごとに被験者の絵 (先生の殓) の左右むき について均衡をとった。

\section{結果}

〈弁别課題成績の年龄比較〉すべてのトレーニングに 通過し，般化テストに掠いて 24 試行中 20 試行以上 $\left(x^{2}\right.$ 検 定で危渝率 $1 \%$ 以下で有意) 正しいラベリングを行った被 験者数は，4歳児10，5歳児12，6歲児12名とほとんよ゙す ベての约罗が明確な左右むきの弁別能力を示しだ。こ の被験者の比率について $\chi^{2}$ 検定を行ったところ, 4 歳児 と他の年齢グループ間に有意差はなかった $\left(\chi^{2}(1)=4.24\right) 。$ 年龄グループごと（課題に失敗した 4 歳児 2 名は除く）のト レーニング $1-3$ の通過に要した平均試行数及び標準偏 差妾 TABLE 1 に示す。どの年齢グループ, トレーニン グに揖いてもほとんど誤りが無く, 個人差む小さかった ことがわかる。各トレーニングごとに試行数について Kruskal-Wallis の悇定を行ったところ, いずれにおい ても年齢グループ間に有意羑はなかった(トレーニング $1,2,3$ の順に $\left.\chi^{2}(2)=0.24,2.64,0.18\right)$ 。

〈表現行動の分析〉弁別課題前後の各翼問シリーズに おいて被験者が示した言語行動, 動作のうち, 左右方向 次元を表現している場合，それを絵の左右むきについて の表現と見なした。観察された表現は「ミギ」「ヒダリ」 という言語表現と, 人差し指による左右方向指示, 左右 方向への手の伸展運動, 左右の挙手などの動作表現の 2

*課題に失敗した 4 歲児 2 名はいずれもトレーニング 1 で $2 つ$ のラベリングを交互に緋り返すのみであった。 
TABLE 1 年龄グループ別のトレーニング通過に 要した平均試行数（括弧内は標集偏差）

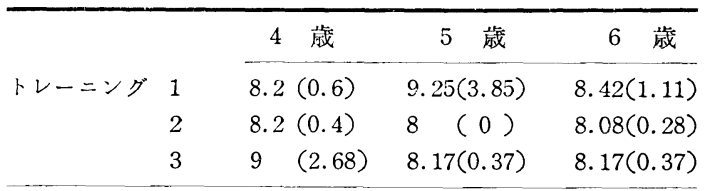

種類に大別された。以下，4歳児の課題後質問について は弁別課題に失敗した 2 名を除いた10名のデータを基に 分析を行う。

TABLE 2 には課題前, 課題後の各質問に対して左右む きの言語, 動作表現を行った被験者の比率を年龄別に示 す。各年齢，両質問シリーズを通じてQ 1 ではむきの表 現を行った被験者は少なく, Q2・3ではほぼすべての被 験者が表現を行った**。Q1 で表現行動を示した被験者 は，Q2 及び Q3 では必ず表現を行った。すべての年齢 を込みにしで***，むきの表現を行った被験者の比率に ついて McNemar 検定を実施したところ，課題前 $\left(x^{2}(1)\right.$ $=21.04)$ 課題後質問 $\left(\%^{2}(1)=9.09\right)$ ともに $Q 1$ より $Q 2 \cdot 3$ の方が $1 \%$ 水準で有意に高かった。Q1 1 Q2 23 に比し， むきの表現を喚起しにくかったことは明らかである。た だし，Q1 に対しても，課題前に比べると課題後では表 現行動を示した被験者の比率は有意に増加した $\left(\chi^{2}(1)=\right.$ $8.07, \mathrm{p}<.01)$ 。

TABLE 3 には Q2, Q3に対して動作，言語いずれの表 現行動を行ったかによって分類した場合の被験者数を示 す****。TABLE 2 において Q2, Q3 を比較すると，5, 6 歳では Q2 では動作表現，Q3 では䓂語表現を行った 被験者の比率がやや高い傾向が見られるが，実際にはほ とんどの被験者において Q2・3 で表現行動は一致して おり，不一致の場合は必ず Q2 で動作，Q3 で言語表現 が行われたことがわかる。表現行動が一致していた被験
者の比率について $\chi^{2}$ 検定を実施したところ*****, 課題 前 $\left(\chi^{2}(1)=8.47, \mathrm{p}<.01\right)$ 課題後 $\left(\chi^{2}(1)=6.44, \mathrm{p}<.02\right)$ 質問 ともに有意な一致傾向が認められた。

FIG. 1 には弁別課題成功者のうち，課題前後の各質問 シリーズを通して動作のみ，動作・言語両方，言語のみ でむきの表現を行った被験者の比率を示す。年齢ととも

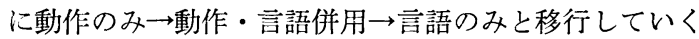
傾向がうかがえる。3つのカテゴリーに属する被験者の 比率については年齢グループ間に差はなかった $\left(x^{2}(4)=\right.$ 6.11）が，言語を使用した被験者の比率について $4-6$ 歳間に有意差 $\left(x^{2}(1)=4.77, \mathrm{p}<.05\right)$ が認められた。

〈言語媒介水準の年龄比較と弁別成績との関連〉

動作表現の場合には, どの被験者においても常に各運 動パターンと絵の左右むきの対応は一貫していたが，言 語表現の場合には課題前後の質問シリーズを通してみる と，あるい恪質閣セッション内ですら「ミギ」「ヒダ リ」と左右むきとの対応が一貫していないケースが多く みられた。そこで，言語符号化技能の所持及び弁別課題 での言語媒介子の使用について以下の判定基準を設定し た。

$\mathrm{A}$ ：課題前質問シリーズ中，一貫した左右対応を保っ て言語表現******が行われていれば，言語符号化技能を 所持していたとする。

B：Aを満たしかつ, 課題後質問シリーズ中, 課題前 と同じ左右対応を一貫して保って言語表現が行われてい れば，弁別課題解決に言語媒介子を使用したと見なす。

上記 2 つの基準によれば，左右むきの弁別課題解決に 際して, 以下の 3 つの言語媒介水準の存在が推定される。 レベル 1：Aさえ満たさない。言語符号化技能を所持せ ず，他の性質の符号を媒介子として弁別課題を解決した。 レベル 2：Aのみ満たす。言語符号化技能を所持してい

TABLE 2 各質問に対してむきの言語 [動作]表現を行った被験者の比率

\begin{tabular}{|c|c|c|c|c|c|c|c|}
\hline \multirow[b]{3}{*}{ Q 1} & \multicolumn{3}{|c|}{ 課 題 前 質 問 } & \multicolumn{4}{|c|}{ 課 題 後 質 問 } \\
\hline & 4 歳 & 5 歳 & 6 歳 & & 4 歳 & 5 歳 & 6 歳 \\
\hline & $8.3[16.7]$ & $33.3[16.7]$ & $25[0]$ & 20 & {$[40]$} & $33.3[33.3]$ & $33.3[41.7]$ \\
\hline Q 2 & $33.3[66.7]$ & $50 \quad[50]$ & $66.7[33.3]$ & 40 & {$[60]$} & $25\lceil 75]$ & $50 \quad[50]$ \\
\hline Q 3 & $41.7[58.3]$ & $75[25]$ & $83.3[8.3]$ & 40 & {$[60]$} & $50[50]$ & $83.3[16.7]$ \\
\hline
\end{tabular}

**6 藏児 1 名のみ, 課題前質問 Q2 で動作表現を行ったが， Q1，Q3では表現行動を行わなかった。

****各年㳼別に集計した場合，課題後質問ではQ2, 3 でのみ表 現を行った被験者数（McNemar 検定における变化項の大 きさ）が 4 以下となり，検定不可能となる。それ故，年歯 グループを込みにして検定を行った。後述の Q1 に対して むきの表現行動を示した被験者の比率に関する課題前・後 の此較検定についても同様である。
**** TABLE 4 の 6 藏児の課題前質問については, Q3 でむ きの表現を行わなかった 1 名を除く11名のデータを基 にしている。

******先の 2 つの検定に合わせて, 年踷グループを込みにし てQ2・3で表現行動が一致・不一致であった被験者数 を理論度数（各50\%ずつ）と比較した。

****** 左むきの絵について「ミギ」, 右むきの絵について「ヒ ダリ」と表現しても，この対応が一貫しておれば良い。 
TABLE 3 Q 2・3 に対するむきの各表現行動 タイプの被験者数

\begin{tabular}{lcccccccc}
\hline & & \multicolumn{3}{c}{ 課題前質問 } & \multicolumn{4}{c}{ 課題後質問 } \\
$\mathrm{Q} 2$ & $\mathrm{Q} 3$ & 4 歳 & 5 歳 & 6 歳 & 4 歳 & 5 歳 & 6 歳 \\
\hline $\mathrm{E}$ & $\mathrm{E}$ & 7 & 3 & & 1 & 6 & 6 & 2 \\
$\mathrm{E}$ & $\mathrm{V}$ & 1 & 3 & 2 & 0 & 3 & 4 \\
$\mathrm{~V}$ & $\mathrm{~V}$ & 4 & 6 & 8 & 4 & 3 & 6 \\
\hline
\end{tabular}

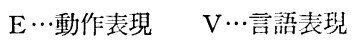

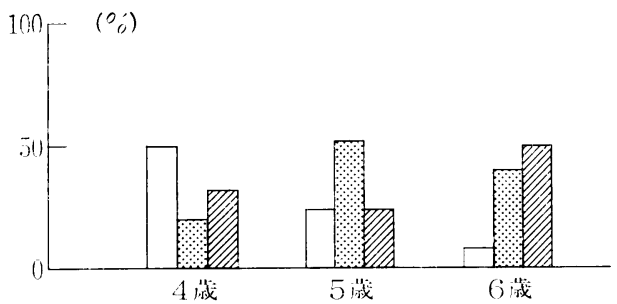

動作表现のみ

FIG. 1 表現行動タイプの年龄変化

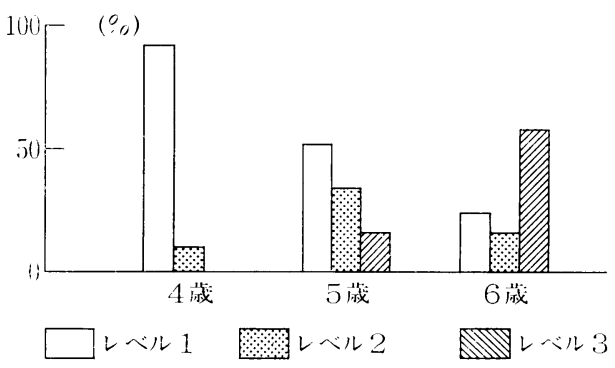

FIG. 2 言語媒介水準の年齢変化

るが，実際の弁別課題解決においては他の性質の符号を 媒介子として使用した。レベル $3: \mathrm{B}$ も満たす。言語符 号を媒介子として弁別課題解決に使用した。

FIG. 2 には, 弁別課題に成功した被験者における前述 の 3 つの言語媒介水準の比率を各年齢グループごとに示 す。年齢とともにレベル 1 は減少, それに相補する形で レベル 3 が増加する傾向がわかる。各レベルに属する被 験者の比率について有意な年龄差 $\left(\chi^{2}(4)=13.65, \mathrm{p}<.01\right)$ がみられた。各年龄グループ間で下位検定を行ったとこ ろ，4-6 歳でのみ有意差が認められた $\left(\chi^{2}(2)=9.31, \mathrm{p}<\right.$ .01)。

TABLE 4 にはトレーニング 1-3 の通過に要した言語 媒介水準ごとに平均試行数及び標準偏差を示す。すでに 年齢グループ別にみたのと同様，どのトレーニングセッ ションにおいても均質でほとんど誤りのない結果になっ ている。各トレーニングごとに試行数について KruskalWallis の検定を行ったところ，いすれれにおいても媒介 レベル間に有意差はなかった（トレーニング $1,2,3$ の順
TABLE 4 言語媒介水準別のトレーニング通過に要 した平均試行数（括弧内は標準偏差）

\begin{tabular}{|c|c|c|c|c|}
\hline & & レベル 1 & レベル 2 & レベル 3 \\
\hline \multirow[t]{3}{*}{ トレーニング } & 1 & $9.11(3.28)$ & $8.14(0.35)$ & $8.11(0.31)$ \\
\hline & 2 & $8.17(0.37)$ & $8 \quad(0)$ & $(0)$ \\
\hline & 3 & $8.67(2.05)$ & $8.14(0.35)$ & $(0)$ \\
\hline
\end{tabular}

$\left.K \chi^{2}(2)=0.28,2.84,2.00\right)$ 。

\section{考察}

FIG. 2 に示されたように, 課題前後の質問セッション におけるむきの表現行動の分析の結果，4-6 葴児には 「ヒダリ」「ミギ」といら言語による左右むきの符号化技 能を所持し, 弁別課題においてそれを媒介子として使用 する (レベル 3)，言語符号化技能を所持しているが弁別 課題において使用しない（レベル2）, 言語符号化技能を 所持しない (レベル1)の3つの水準が存在し, 漸次より 高度な水準へと年踹変化する傾向が認められた。しかし， TABLE 2 にみられたようにどの水準にあろうと弁別課題 の成績は良好で, 水準閒には差はなかった。すなわち, 吾語による符号化・媒介を行わずとも (レベル 1,2$)$, 行 った場合と同様に効率よく左右反転弁別課題を解決しう ると言えよう。既に，カードに描かれた図形数の弁別課 題 (Estes, 1976) や玩具の提示位置の再生課題 (Ryan, et. al, 1970) において, 幼児は言語以外の媒介子を使用して 課題解決するのではないかという報告がある。ただし， 各課題において処理されるべき概念の性質を考慮してお くべきであろう。Blank (1974) によると, 時間間隔のよ うに知覚的に直接䫓現していない世界に由来する概念を 扱う際 (例兑ば，点隇回数の異なるランプの弁別)には言語に よる符号化が不可欠だという。左右のむきのような空間 概念は感覚運動的に，あるいは視覚映像によって把握さ れやすい性質を有している故，言語による符号化・媒介 の必要性がないのかもしれない。

それでは言語以外のいかなる性質の媒介子が弁別課題 に使用されたのだろうか。言語による以外のむきについ ての表現としては，指を使っての左右方向指示，左右方 向への手の伸展運動などの動作表現が観察された。これ ら動作表現は，「アッチ」「コッチ」など方向性の指示語 を伴って行われたところから，特定対象の位置を指示す る機能をもった指さし行動に起源するものと推測される。 このような動作は弁別課題遂行中には観察されなかった が, 本課題に関する限り, 映像的というょり感覚運動的 な符号が媒介子として使用されたと推論するのが妥当で あろう。というのも，多種多様な絵のむきを代表する映 像といったものは想定困難であるからである。 
また，左右むきの表現行動の分析結果，年長児ほど左 右反転弁別に際し言語による媒介を行う割合が高くなる ことが見いだされた。FIG.2によると言語による媒介は 5 歳から開始するが，6歳で顕著になる。ただし，4歳 児ではレベル 3 にある被験者はいなかったのに対し，6 歳時でもレベル 1 の被験者が存在し、レベル 3 は半数程 度に達したに過ぎなかったことからして，上記の年龄変 化傾向流就学後も続くと推定される。この点に関しては, 一連の提示対象の記憶再生に㧍ける研究結果 (Conrad, 1971 参照）と一致する。さらに，本研究では，言語によ る符号化技能を所持していながら，それを弁別課題にお いて媒介子として使用しない水準 (レベル2)の存在が明 らかにされた。これは，いわば完全なる言語媒介への移 行段階と考えられるが，いかなる意味で不完全な段階に あるのか解釈は難しい。例えば，志語媒介子を所産でき る可能性をもっているが，何等かの理由で弁別学習課題 においては所産しなかった(所産欠如)のかもしれないし 弁別課題中も潜在的な言語的媒介子を所产していたのだ が，それによってラベリング反応が統制されなかった (統制火㚼)のかもしれない(リーズ，1982参照)。上記の点 を明らかにするた为には，言語媒介技能の訓練を施し， その後自発的にその技能を使用するか否かを㭘討する必 要があるが，その際，弁別課題中に音語媒介の存否を示 す測度を得なければならない。

幼巟が弁別次元について言語表現できなくとも弁別課 題に成功したといら結果は，てがかり獲得示差性仮説 （示差的矣言語ラベルによって類似した刺激間の示差性が高季り， その結果升別反応が促准されるとする； スチーブンソン， 1980 参照)のような，吾語が知觉的なてがかりを与える上で 役立っているといった教え方に疑問を提起するものであ る。むしろ，刺激を弁別しらるてがかりが知覚されてい るからこそ，分化的なラベリングが可能であると将える 方浽当であろう。さらに，本研究で明らかにされた䓂 語媒介への移行段階の存在は, 幼児にとって単に左右の むきを表現するために言語を使用少ることと，てれら言 語を禁介として弁別課題を解決することと注明らかに異 なる技能であって，後者はやや打くれて発達することを 示すものである。左右反転弁別における言語媒介は，そ れ於課題解決に必要不可欠な方略としてではなく，幼児 の言語的技能の熟達につれて使用しうる新たな別個の方 略として発達して行くといえよう。

$$
\text { 付 記 }
$$

本实験試行に際し，奈良県広陵町立北保育所，同北幼 稚園に御協力頂きました。厚く御礼申し上げます。

\section{引用文献}

Asso, D., \& Wyke, M. 1970 Visual discrimination and verbal comprehension of spatial relations by young children. British Journal of Psychology, 61, 99-107.

Blank, M. 1974 Cognitive functions of language in preschool years. Developmental Psychology, 10, 229-245.

Caldwell, E.C., \& Hall, V.C. 1969 The influence of concept training on letter discrimination.

Child Development, 40, 63-71.

Conrad, R. 1971 The chronology of the development of covert speech in children. Developmental. Psychology, 5, 398-405.

Davidson, H.P. 1935 A study of the confusing letters b, d, p and q. Journal of Genetic Psycho$\log y, 47,458-468$.

Estes, K.W. 1976 Nonverbal discrimination of more and fewer elements by children. Journal of Experimental Child Psychology, 21, 393-405.

Flavell, J.H. 1971 The uses of verbal behavior in assessing children's cognitive abilities. In D.R. Green, M.P. Ford, \& G.B. Flamer (Eds.) Measurement and Piaget. New York: McGraw-Hill.

Gelman, R. 1978 Cognitive development. Annual Revierv of Psychology, 29, 297-332.

橋本憲尚 1985 幼肾の左右反転弁別に打ける判断次元 示唆の効果 教育心理学研究, 33, 76-80.

勝井 晃 1971 方向の認知に関する発達的硎究 風間 書房.

Laurendeau, M., \& Pinard, A. 1970 The development of the concept of space in the child. New York : International Universities Press.

Reese, H.W. 1978 Imagery and associate memory. In R.V. Kail, \& J.W. Hagen (Eds.), Perspectives on the development of memory and cognition. Hillsdale, N.J. : Erlbaum.

リーズ，H.W. 杉村健(訳) 1982 子どもの学習過程 サイエンス社. (Reese, H.W. 1976 Basic learning. processes in childhood. New York : Holt.)

Rudel, R.G., \& Teuber, H.L. 1963 Discrimination of direction of line in children. Journal of Comparative and Physiological Psychology, 56, 892898.

Ryan, S.M., Hegion, A.G., \& Flavell, J.H. 1970 Nonverbal mnemonic mediation in preschool children. Child Development, 41, 539-550.

スチーブンソン, H.W. 相田貞夫他(訳) 1980 児童の 学習心理学 田研出版 (Stevenson, H.W. 1972 Children's learning Englewood Cliffs, N.J. : Prentice-Hall.)

Wohlwill, J.F. 1960 Developmental studies of perception. Psychological Bulletin, 57, 249-288.

（1988年1月14日受稿） 